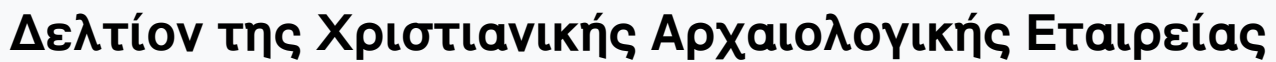

Tó 26 (2005)

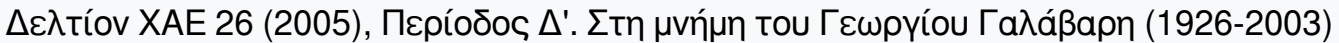

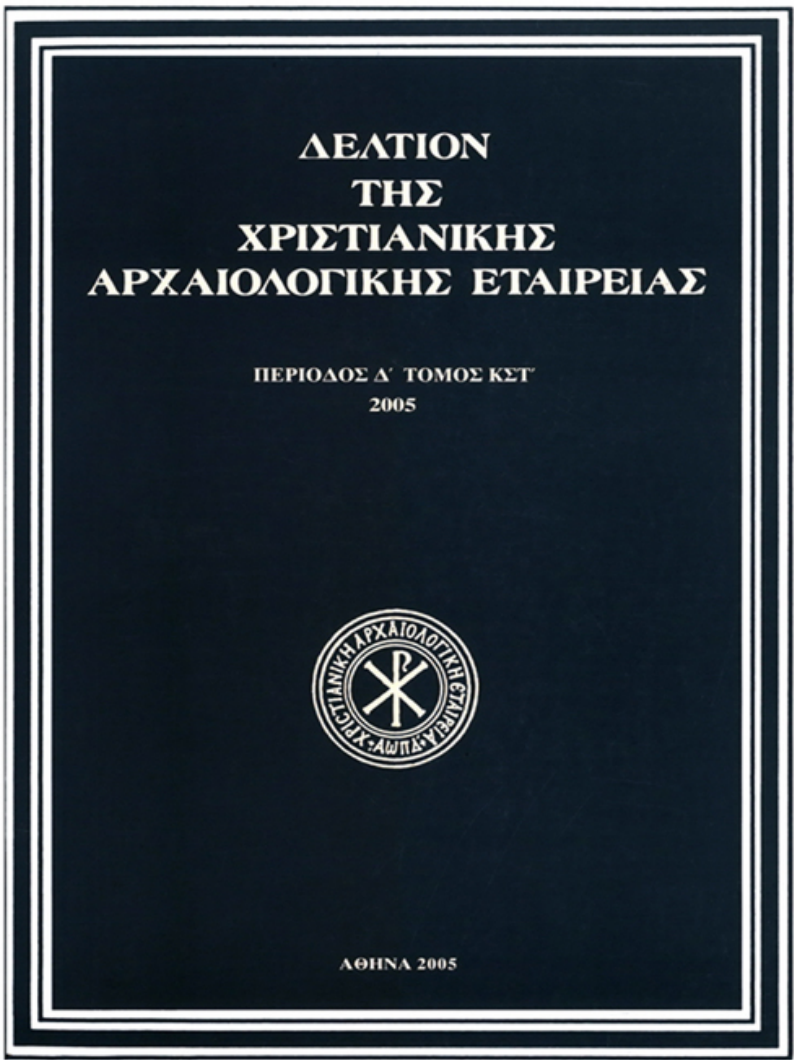

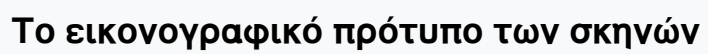

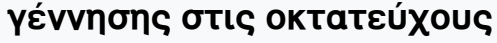

Mati MEYER

doi: $\underline{10.12681 / \text { dchae.449 }}$

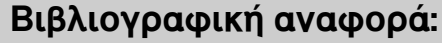

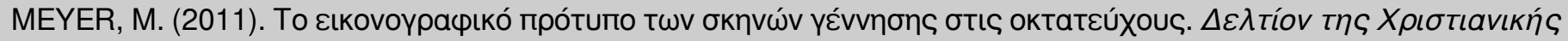

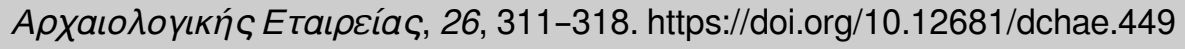




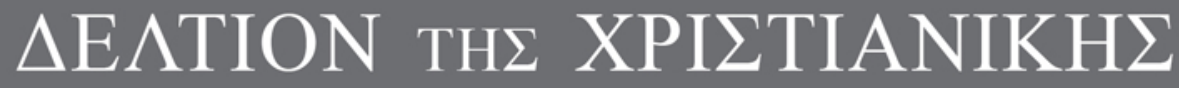 APXAIO $\Lambda$ ОГКН $\Sigma$ ETAIPEIA $\Sigma$}

On the Hypothetical Model of Childbearing Iconography in the Octateuchs

Mati MEYER

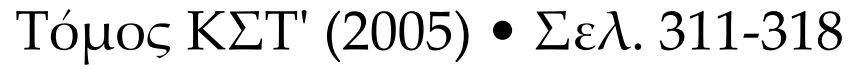

A@HNA 2005 


\author{
Mati Meyer
}

\title{
ON THE HYPOTHETICAL MODEL OF CHILDBEARING ICONOGRAPHY IN THE OCTATEUCHS*
}

\begin{abstract}
$\mathrm{T}_{\mathrm{h}}$ sentially in the eleventh- to thirteenth-century Octateuchs and in the only extant copy of the Book of Kings, Vat. gr. $333^{2}$, represents two different schemas: one, a 'realistic rendering', as labeled by Kurt Weitzmann and Massimo Bernabò, was used in certain scenes of childbearing, drawing on an unidentified illustrated medical treatise ${ }^{3}$; the other, 'l'enfantement sans douleur', as coined by Jacqueline Lafontaine-Dosogne, is related to the birth of the Virgin ${ }^{4}$ and was adapted for other biblical scenes of birth ${ }^{5}$. We shall argue below that the Octateuch does not present two unrelated schemas of childbearing, but rather one abridged iconography of the pre- and post-partum stages originating in its archetype. We shall also suggest that the source of this specific iconography is a now lost illustrated manuscript of the
\end{abstract}

\footnotetext{
* This article is based on a chapter of the author's L'image de la femme biblique dans les manuscrits byzantins enluminés de la dynastie macédonienne (867-1056), unpublished Ph.D. diss., Hebrew University of Jerusalem, 2001, 115-41.

${ }^{1} \mathrm{~K}$. Weitzmann and M. Bernabò with the collaboration of R. Tarasconi, The Illustrations in the Manuscripts of the Septuagint, II: Octateuch, Princeton 1999, 2 vols (hereafter: Octateuch).

2 J. Lassus, Lillustration byzantine du Livre des Rois: Vaticanus graecus 333, BCahArch 9, Paris 1973.

${ }^{3}$ Weitzmann and Bernabò, Octateuch, 304, n. 42, with earlier bibliography.

${ }^{4}$ Iconographie de l'enfance de la Vierge dans l'empire byzantin et en occident, Bruxelles 1964, vol. I, 89-121, esp. 93, n. 2 (hereafter: Iconographie del'enfance).

${ }^{5}$ Weitzmann and Bernabò, Octateuch, 45, 308. For the discussion of both theological and political-imperial reasons for the choice of a particular formula, well beyond the scope of this article, see the author's $\mathrm{Ph}$. D. dissertation, L'image de la femme biblique (n. $), 142-75$.

${ }^{6}$ Soranus undoubtedly acquired his medical knowledge and obstetrical techniques in Alexandria, but practiced mainly in Rome (98-138 A.D.) among the aristocratic families (A.E. Hanson and M.H. Green, Soranus of Ephesus: Methodicorum princeps, $A N R W 37 / 2,1994,981-82$ ) (hereafter: Soranus).

${ }^{7}$ D. Gourévitch, La gynécologie et l'obstétrique, ANRW 37/3, 1996, 2085-86.
}

Gynaikeia, yet is still traceable in Western illuminated manuscripts.

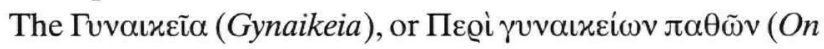
Women's Diseases), is an obstetrical and gynaecological treatise written by the second-century physician Soranus of Ephesus ${ }^{6}$. It is the first medical work to formulate a rational gynaecology for midwives ${ }^{7}$. Soranus was a prolific writer who was held in high esteem in the Byzantine world ${ }^{8}$, and fragments of his works were frequently copied ${ }^{9}$. Although his Gynaikeia in Greek has been preserved only fragmentarily, it was reconstructed from extant Medieval Latin adaptations, which had also attained similar acclaim ${ }^{10}$ : Avianus Vindicianus (4th c.) $)^{11}$; Caelius Aurelianus (5th c. $)^{12}$; and the anonymous Muscion or Mustio (6th c.) ${ }^{13}$. A certain Moschion (6th c.) published a new Byzantine 'translation' from

\footnotetext{
${ }^{8}$ Soranos, Gynaikia (P. Burguière, D. Gourévitch and Y. Malinas, trans. and eds., Soranus d'Éphèse: maladies des femmes, Paris 1988, vol. I, XXXIX-XL). This annotated edition of the original Gynaikeia is the most comprehensive and updated study of the medical treatise (ibid., vols I-IV, 1988, 1990, 1992, 2000 (hereafter: Soranos, Gynaikia).

${ }^{9} \mathrm{See}$, for example, the seventh-century Greek physicians Orion (Hanson and Green, Soranus, 1021) and Meletius the Monk (ibid., 10211023; R. Renehan, Meletius' chapter on the eyes: an unidentified source, DOP 38 (1984), 159-68); the encyclopaedists Oribasius, 325-403 (Oeuvres d'Oribase, U.C. Bussemaker and Ch. Daremberg, eds., V, Paris 1851-1873) and Paul of Aegina, 625-696 (The Seven Books of Paulus Aegineta, F. Adams, ed., 3 vols, London 1844-1847, esp. vol. I, 1-16).

${ }^{10}$ On the historiography of Soranus' writings and the problems regarding his Latin translators' identity, as well as the reconstruction of the original text of the Gynaikeia, see Hanson and Green, Soranus, 970-80, 1042-60. See also M. Green, The Transmission of Ancient Theories of Female Physiology and Disease Through the Early Middle Ages, Ph. D. diss., Princeton University 1985, 135-39.

${ }^{11}$ Hanson and Green, Soranus, 1045.

12 This is the most faithful Latin translation of Soranus' original text (Caelius Aurelianus, "Cynaecia». Fragments of a Latin Version of Soranus' Gynaecia from a Thirteenth Century Manuscript, M.F. Drabkin and I.E. Drabkin, eds., Baltimore 1951).

${ }^{13}$ Mustio, i.e. Sorani gynaecionum vetus translatio Latina, V. Rose, ed., Leipzig 1882. See also G. Baader, Der Hebammenkatechismus des
} 
the Latin version of the Gynaecia Muscionis, a text conflated with that of the Byzantine physician Aëtius of Amida (510-

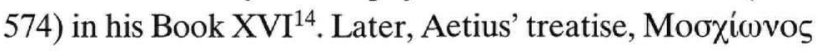

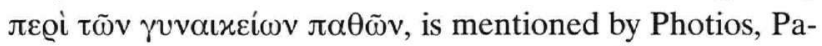
triarch of Constantinople (858-867, 877-886) ${ }^{15}$.

The theory maintained by modern scholarship, that Soranus' original treatise was abundantly illustrated, is significant to our argument. In the fifteenth-century Parisinus gr. 2153, which contains various writings of Soranus and Aetius of Amida (a copy of an earlier manuscript of an unknown date $)^{16}$, the artist shares with his readers the reason why he left six folios empty between Chapters 44-45: "Here one has to insert each one of the pictures of the manipulation of fetuses and how the maia helps to push out each one with the explication of a picture. We have renounced [reproducing the schemas] because [of the missing] colors" ${ }^{\prime 17}$. If this remark is genuine, then the empty folios should have contained polychrome drawings resembling those appearing on the ninth-tenth-century Bruxellensis 3714, a copy of a sixth-century Latin adaptation of Muscion's Gynaikeia ${ }^{18}$, depicting clinical illustrations of foetus-in-utero. What is more, the sixth-century manuscript maintains that it would be pointless to include some of the illustrations that existed in the Soranus' original manuscript ${ }^{19}$. The casualness of this remark suggests that the illustrations in the Greek original were so abundant that the copyist could be selective about which pictures he wished to incorporate into the Latin version ${ }^{20}$.

The Gynaikeia comprises four books ${ }^{21}$. Book II, written for the midwife, deals with the uncomplicated delivery occurring in ideal conditions; Soranus instructs the midwife on the young mother's delivery and mental well-being; further on, he explains the post-partum stages, dispensing useful instructions on how to care for the young mother and the newborn ${ }^{22}$. A comparison between the medical text and the 'realistic' schema of birth ${ }^{23}$, which presents visual elements hitherto unquestioned, may furnish clues that could support our argument regarding the hypothetical model of childbearing.

The Byzantine illustrations always show the young mother against an architectural background, a Byzantine convention for depicting an interior setting. She is clad in a short, lightweight tunic drawn above her knees; her distended belly and heavy breasts, free of the usual constraining band, indicate that she is pregnant. Although she usually wears a headdress - a paenula or a phaskolion ${ }^{24}$ - which is a visible sign of
Muscio - ein Zeugnis frühmittelalterlicher Geburtshilfe, in W. Affeldt, Frauen in Spätantike und Frühmittelalter. Lebensbedingungen - Lebensnormen - Lebensformen, Sigmaringen 1990, 115-25.

${ }^{14}$ Aetios of Amida, The Gynaecology and Obstetrics of the VIth Century A.D., J.V. Ricci, ed., Philadelphia 1950. See also Soranos, Gynaikia, vol. I, XLVIII-XLIX.

${ }^{15}$ Bibliotheke 221 (Photius, Bibliothèque, trans. and ed. R. Henry, Paris 1962, vol. III, 140, 150).

${ }^{16}$ Soranus' original text, On Women's Diseases, was reconstructed from this manuscript (J. Ilberg, Die Überlieferung der Gynäkologie des Soranus, AbhLeipzig, 28.2., Leipzig 1910, 11-24).

${ }^{17}$ Hanson and Green, Soranus, 1024, n. 201. See also Soranos, Gynaikia, vol. I, LIII.

${ }^{18}$ Muscio, Gen. II, 24 (Rose, Sorani gynaeciorum, 105.16-21). See also Hanson and Green, Soranus, 1023-24, n. 197).

${ }^{19}$ MS 3714, fols 16v, 26v, 27-27v, 28-28v, 29 (J. Ilberg, Der Gynäkologie des Soranus, pls III-VI).

${ }^{20}$ Hanson and Green, Soranus, 1024, n. 198; 1046-61, 1072-73. It is noteworthy that Soranus' 'Bandages' in a ninth-tenth-century Florentine manuscript is accompanied by sixty illustrations (Bibl. Medic. Laur., Plut. 74, 7 (Ilberg, Sorani Gynaecionum Libri IV; de signis fracturatum; de fasciis; vita Hippocratis secundum Soranum, Leipzig and Berlin 1927, pls I-XV).

${ }^{21}$ Soranos, Gynaikia, vol. I, LXXXVIII-C.

22 Sor., Gyn. I.i (O. Temkin et al., Soranus' Gynecology, Baltimore and London 1956, 3-4: hereafter: Soranus' Gynecology).

${ }^{23}$ This schema, with some variants, is adopted for the following figures:
1. Hagar giving birth to Ishmael (Gen. 16:15; Octateuch, Rome, Bibl. Apost. Vat. Sarayi Library gr. 747, ca. 1070, fol. 37v; Octateuch, Istanbul, Topkapi, cod. G. I. 8, ca. 1139-1152, fol. 75r (the scene is badly flaked); Octateuch, Smyrna (Olim), Evangelical School Library, cod. A.I, ca. 1150 , fol. 29v; Octateuch, Rome, Bibl. Apost. Vat., gr. 746, fol. 71r (Weitzmann and Bernabò, Octateuch, 73, figs 240b, 242-244). 2. Lot's younger daughter giving birth to Ben-Ammi (Gen. 19: 37-38; Vat. gr. 747, fol. 41r; Sm., fol., 32v; Vat. gr. 746, fol. 77v (Weitzmann and Bernabò, Octateuch, 81, figs 283-285). In the Ser. there is an empty space for a non-executed miniature. 3. Rebecca giving birth to Esau and Jacob (Gen. 25:24-26; Vat. gr. 747, fol. 46v; Ser., fol. 95v; Sm., fol. 38r; Vat. gr. 746, fol. 89v (Weitzmann and Bernabò, Octateuch, 94, figs 355-358). 4. Rachel giving birth to Benjamin (Gen. 35:24-26; Vat. gr. 747, fol. 56v; Ser., fol. 119r; Sm., fol. 48r or 48v; Vat. gr. 746, fol. 113r (Weitzmann and Bernabò, Octateuch, 112, figs 447b-450b). 5. Tamar giving birth to Pharez and Zarah (Gen. 38: 29-30, Vat. gr. 747, fol. 59v; Ser., fol. 126r; Sm., fol. 51v; Vat. gr. 746, fol. 119v (Weitzmann and Bernabò, Octateuch, 119-120, figs 479b-482b). Two more miniatures depict Hannah giving birth to Samuel and another child in the Vaticanus Book of Kings, cod. gr. 333, fols 5v, 7r (I Sam. 1:19-21; 2:20-21, Lassus, Livre des Rois, 33, 35; figs 3b, 6a(1), respectively). For a discussion of these examples, see the author's Ph.D. dissertation (see n. *), 116-17.

${ }^{24} \mathrm{~A}$ bonnet or a sort of turban worn by Byzantine women (M. Emmanuel, Some Notes on the External Appearance of Ordinary Women in Byzantium: Hairstyles, Headdresses: Text and Iconography, ByzSl 56 (1995), 772-73). 


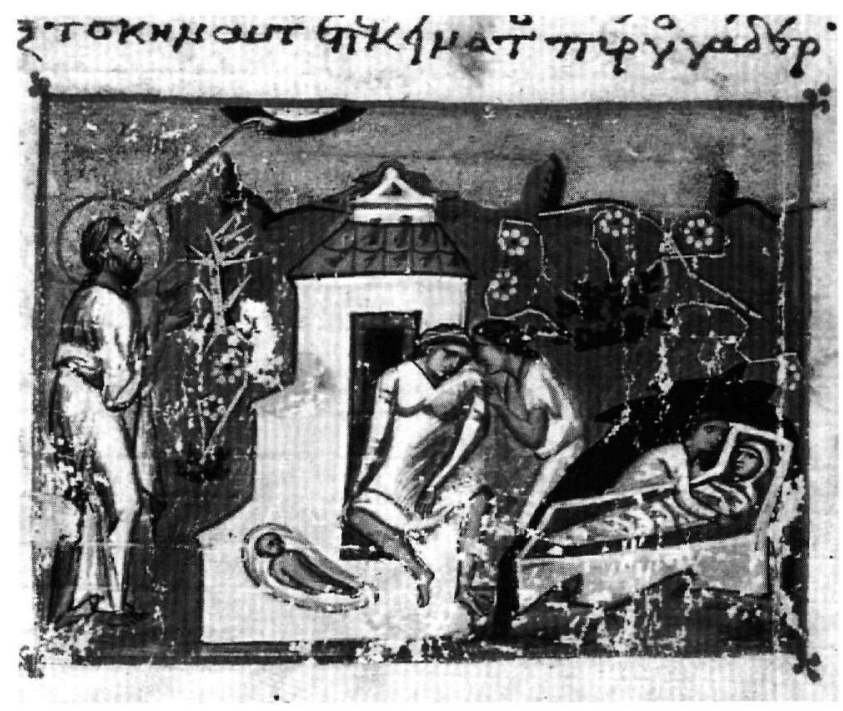

Fig. 1. Rachel giving birth to Benjamin, Rome, Lib. Apost. Vat., gr. 747, fol. 56v, c. 1070 (photo: Biblioteca Apostolica Vaticana).

her marital status ${ }^{25}$, or white bands, her hair is dishevelled ${ }^{26}$. All these features are illustrated in the depiction of Rachel in Vat. gr. 747, fol. 56v (Fig. 1) and Lot's daughter in Vat. gr. 746 , fol. $77 \mathrm{v}$ (Fig. 2). The parturient, facing front, is seated on a bench (designating the birthing stool of late antique imagery $)^{27}$, or crouching, her legs wide apart, pressing one hand against her uterus and the other on the midwife's head; both gestures indicate labor pain, as exemplified by the figure of Rebecca giving birth in Vat. gr. 747, fol. 46v (Fig. 3). The midwife, seated on the ground or on a low stool beside the parturient, usually on her right (Fig. 2), supervises the infant's egress. The woman depicted is giving birth to one or two infants; one is represented 'plunging forward', head first, from his mother's legs, while the other appears lying on

\footnotetext{
${ }^{25}$ The headdress may be understood as a later addition, since Byzantine decorum demanded the married woman's head to be covered (L. Garland, The Life and Ideology of Byzantine Women: A Further Note on Conventions of Behaviour and Social Reality as Reflected in Eleventh and Twelfth Century Historical Sources, Byz 58 (1988), 371).

${ }^{26}$ A close depiction, where the woman about to deliver is crouching and pulling at her dishevelled hair, appears in the tenth-century Kynegetica of Oppian, a copy of a pre-iconoclastic model. The violent gesture signi-

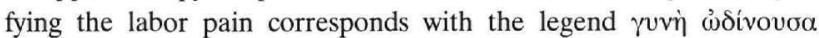
('woman in painful birth') accompanying the miniature (Venice, Bibl. Marc., cod. gr. Z. 479 [=881], ca. 1062, fol. 14r, Cynegetika of Oppian, I: 468-479 (I. Furlan, Codici greci illustrati della Biblioteca Marciana, Pado-
}

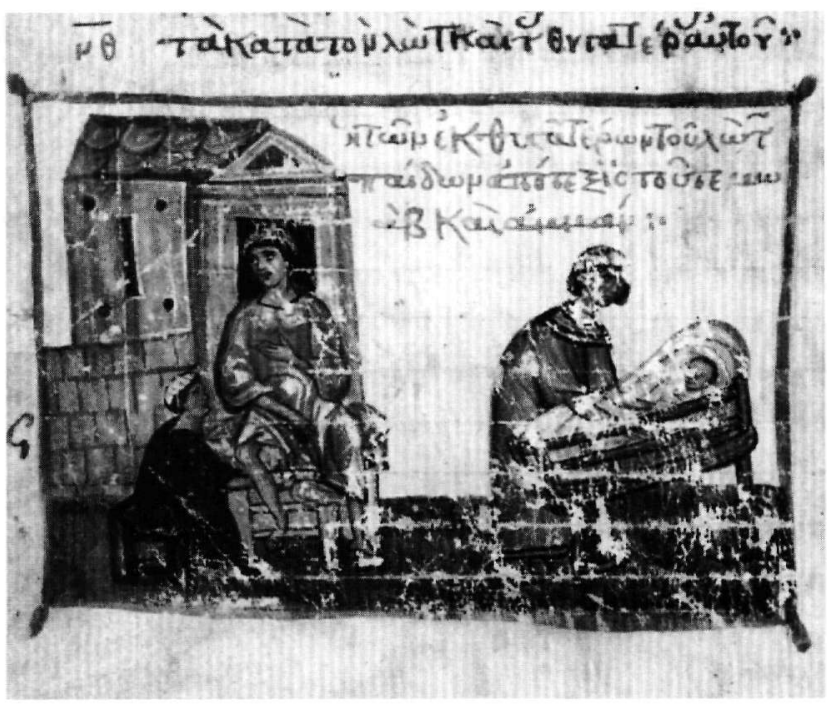

Fig. 2. Daughter of Lot bearing Ben-Ammi; a second daughter attending to Moab, Rome, Lib. Apost. Vat., gr. 746, fol. 77v, c. 1150 (photo: Biblioteca Apostolica Vaticana).

the ground; alternatively, the newborn is shown lying on a sort of couch in front of his mother or at her side (Fig. 1).

The ancient custom of giving birth at home, which is illustrated in the miniatures, is mentioned by Soranus ${ }^{28}$. The lightweight garment of the parturient and her dishevelled appearance are also echoed in the text, where the physician encourages the midwife to let the woman act according to her whims, even if this may seem bizarre, in order to ease her labor pain:

"... for the unhindered passage of the breath, it is necessary to loosen their [parturients] girdles as well as to free the chest of any binder, though not on account of the vulgar conception according to which womenfolk are unwilling to suffer any fetter and thus < also $>$ loosen the

va 1988 , vol. V, 32, fig. 26).

${ }^{27} \mathrm{See}$, for example, the second-century terracotta relief from the tomb of the midwife Scribonia Attice Amerino in the cemetery of Isola Sacra in Ostia, preserved in the local museum, where the parturient is seated on just such a chair (G. Calza, La necropoli del Porto di Roma nell'Isola Sacra, Rome 1940, 248-49, fig. 148). The seated position is equally mentioned in a sepulchral epigram by Agathias Scholastus, c. 532-d. c. 580 (Anthologiae graecae VII, no. 583 (=The Greek Anthology, W.R. Paton, ed., London-New York, 1935, vol. II, 312).

${ }^{28}$ Sor., Gyn. II.ii.2 (67)-II.iii.4 (67-68) (Temkin, Soranus' Gynecology, 70-71). 


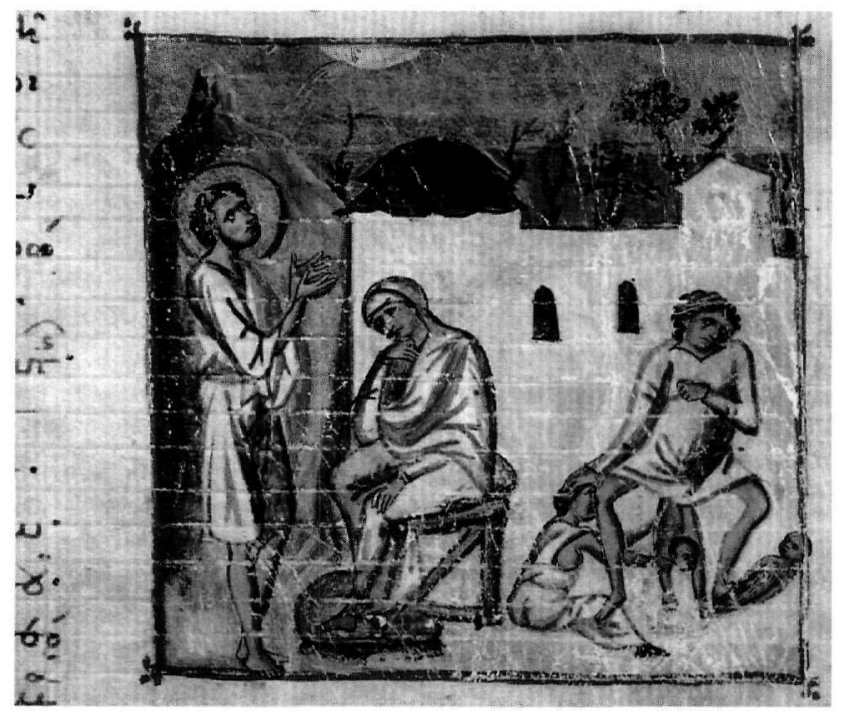

Fig. 3. Rebecca giving birth to the twins Esau and Jacob, Rome, Lib. Apost. Vat., gr. 747, fol. 46v, c. 1070 (photo: Biblioteca Apostolica Vaticana).

hair; it is rather for the above-mentioned reason that even loosening the hair possibly effects good tonus of the head" 29 .

When labor begins, the parturient should be seated on the birthing stool next to the midwife ${ }^{30}$. As we have seen, Rebecca is pressing down on her uterus (Fig. 3), a gesture exhibiting the need to activate the uterus at the moment of delivery, as Soranus puts it: "And the servants standing at the sides should softly press the mass down towards the lower parts with their hands" 31 . Moreover, the Greek doctor recommends that now "there should be three women helpers, capable of gently allaying the anxiety of the gravida even if they do not happen to have had experience with birth. Two of them should be at the sides and one behind holding the parturient woman so that she may not sway with $<$ the $>$ pains"32. Though absent in the Octateuchs, both elements - the servants and the applied pressure - are present in the depiction of Rebecca giving birth in the sixth-or seventh-century Latin Ashburnham Pentateuch ${ }^{33}$. Seated frontally on an obstetrical stool, her legs wide apart and assisted by a midwife kneeling before her, she is held down by two women; the one on the left supports her from behind with her left hand while pressing on the uterus with her right hand. The full schema of childbearing is also preserved in the miniature of a laboring woman in a thirteenth-century Latin compilation of ancient medical texts ${ }^{34}$, wherein two women assist the parturient and a third stands behind the obstetrical stool, gently placing her right hand on the parturient's left breast. The midwife, seated on a low stool on the right, is administering coriander seeds to the woman to induce her labor, as the text indicates ${ }^{35}$. We should note the striking similarity between this midwife's gesture toward the woman's genitalia and that of the midwife assisting Lot's daughter (Fig. 2), only here the midwife is seated on the left. Thus, it is reasonable to assume that since the copyist of the Octateuch drastically condensed the original four-female presence into one, he also had to transfer the blatantly realistic gesture of activating the uterus to the parturient.

As for the midwife, it seems that the Byzantine artist copying from the illuminated Gynaikeia closely followed Soranus' advice that the midwife should "sit down opposite and below the laboring woman; for the extraction of the fetus must take place from a higher towards a lower plane... the midwife, with legs parted and bending the left one forward a little to make it easy to work with the left hand, should sit down and, $\ldots$ in front of the laboring woman"36. The iconographic schema shows the midwife at the parturient's side in profile, and not in front of her; the alteration may be due to the

\footnotetext{
${ }^{29}$ Sor. Gyn. II. iii.6 (70b) (Temkin, Soranus' Gynecology, 74-75).

${ }^{30}$ See above, n. 28.

${ }^{31}$ Sor. Gyn. II.iii.6 (70b) (Temkin, Soranus' Gynecology, 76). For the hypothetical visual reconstruction of the physician's recommendations see Soranus, Gynaikia, II, 68, n. 5, drawings 2-3; 73, n. 24, drawing 9).

${ }^{32}$ Sor. Gyn. II.iii.5 (70a) (Temkin, Soranus' Gynecology, 73).

${ }^{33}$ Paris, B.N.F., nouv. Acq. Lat. 2334, fol. 22v (D. Hoogland Verkerk, Biblical Manuscripts in Rome 400-700 and the Ashburnham Pentateuch, in J. Williams, ed., Imaging the Early Medieval Bible, University Park, Pa. 1999, 104, fig. 1).

${ }^{34}$ Vienna, Öst. Natbibl., cod. 93, fol. 102r (Medicina Antiqua. Libri quattuor Medicinae, codex Vindobonensis 93 der Österreichischen National-
}

bibliothek, C.H. Talbot and F. Unterkircher, eds., Graz 1972, 11 (facsimile). H. Grape-Albers relates this illumination to an iconographical tradition of Late Antiquity, yet without mentioning a possible influence of an illuminated manuscript (Spätantike Bilder aus der Welt des Arztes: Medizinische Bilderhandschriften der Spätantike und ihre mittelalterliche Überlieferung, Wiesbaden 1977, 81-82, fig. 184). See also Weitzmann and Bernabò, Octateuch, 304, n. 42, with earlier bibliography, fig. 15 in the text.

${ }^{35}$ The use of certain substances for dilating the birth canal is attested, for example, in a seventh-century case (W. Fink, "Geburtshilfe" in Byzanz. Zwei Beispiele aus dem frühen 5. Jahrhundert, JÖB 36 (1986), 29).

${ }^{36}$ Sor. Gyn. II.iii.5 (70a) (Temkin, Soranus' Gynecology, 74). 


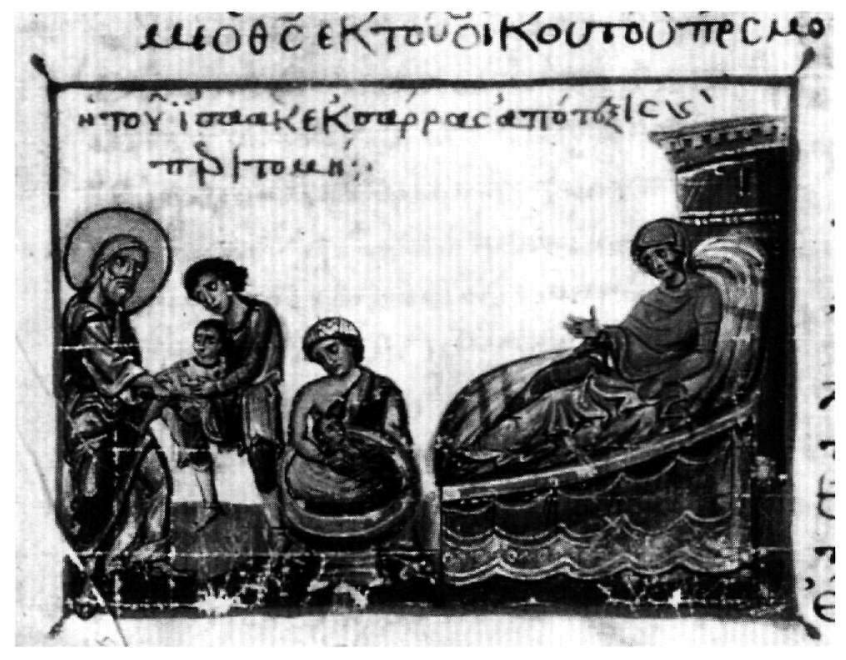

Fig. 4. Sarah giving birth to Isaac, Rome, Lib. Apost. Vat. gr. 746, fol. 79r, c. 1150 (photo: Biblioteca Apostolica Vaticana).

Byzantine artistic inclination to make every element visible in the composition ${ }^{37}$.

When discussing the foetal positions, Soranus acknowledges that the head presentation with arms beside the legs is the only 'normal' one ${ }^{38}$. This position, which was probably present in the original illustrated manuscript, as Par. gr. 2153 attests $^{39}$, found its way into the Octateuchs, where it serves as the stock-type for the depiction of the 'realistic' birth. The portrayal of the infant lying beside his mother's side on a

\footnotetext{
${ }^{37}$ This position of the parturient, the midwife, and others was reconstructed in the French edition of Soranus's Gynaikeia based on the details furnished by the physician himself and by the extant iconography of childbearing (Soranos, Gynaikia, vol. II, 68-69, n. 5; 73, n. 24, drawing 10). See also D. Gourévitch, La grossesse et l'accouchement dans l'iconographie antique, Dossiers de l'archéologie 123 (1988), 42-48.

${ }^{38}$ The description of this position is missing from the Greek version of the Gynaikeia due to a lacuna of $301 / 5$ lines, but is cited in the translations of Caelius Aurelianus and Muscio: "When the bag is sufficiently open, the head of the fetus is driven out next; for thus it is carried when nature fulfills her duty properly. And the birth is even more favorable when (the fetus) descends with its face turned downwards" (Temkin, Soranus' Gynecology, 75, n. 16).

${ }^{39}$ See above, n. 16.

${ }^{40}$ Sor. Gyn. II.ii.2 (67) (Temkin, Soranus' Gynecology, 70).

${ }^{41}$ The following female figures, with slight differences, are depicted according to this schema: 1. Enoch's mother (Vat. gr. 747, fol. 26r; Ser., fol. 50v; Sm., fol. 17r; Vat. gr. 746, fol. 46r (Gen. 4:17; Weitzmann and Bernabò, Octateuch, 45, figs 107c-110c). 2. Sarah, Isaac's mother (Vat. gr. 747, fol. 42r; Sm., fol. 33v; Vat. gr. 746, fol. 79r (Gen. 21:25; Weitz-
}

sort of couch can also be linked to Soranus, who instructs the midwife to prepare "a pillow that the infant may be placed upon it below the parturient woman, till the afterbirth" 40 .

The juxtaposition of the pre-partum stages described in Soranus' text and the iconographic elements of the 'realistic' birth allow us to conjecture that the Byzantine copyist, drawing on an illuminated Gynaikeia, chose to condense the most significant elements that convey the multifaceted aspects of childbearing into one succinct image.

We shall now turn to the depiction of the 'painless birth', represented by an abridged Soranian post-partum formu$\mathrm{Ia}^{41}$. The young mother, resting on a large pillow placed on a bed set in front of a conventional building, wears a long tunic, her head covered by palla or paenula, and her face expressing exhaustion (see, e.g., Sarah after the Isaac's birth in Vat. gr. 746, fol. 79r; Fig. 4). The midwife, seated on the ground or on a low stool, bathes the newborn in a basin near the mother's bed, sometimes assisted by a servant. Alternatively, the baby may be depicted after his bath, lying swaddled in a cradle (see, e.g., Samson in Vat. gr. 746, fol. 490r; Fig. 5). One or two women approach the bed of the young mother, offering her food or presents ${ }^{42}$.

In Book II of the Gynaikeia, Soranus describes at length the post-partum stage, wherein the midwife should tend to both mother and infant. She is first to make sure that the young mother, who was scantily dressed, was now fully clad to keep warm, and resting ${ }^{43}$. After the midwife established that the mann and Bernabò, Octateuch, 82, figs 289b-291b). 3. Yochebed, Moses' mother (Ser., fol. 156r; Sm., fol. 64r; Vat. gr. 746, fol. 152r (Ex. 2:1-2; Weitzmann and Bernabò, Octateuch, 144-45, figs 596-598). 4. Samson's mother (Vat. gr. 746, fol. 490r; Octateuch, Athos, Vatopedi Monastery, cod. 602, fol. 436v (Judg. 13:24; Weitzmann and Bernabò, Octateuch, 286, figs 1491-1492).

The birth of David in the Psalter of the Vatican, Rome, Bibl. Apost. Vat. gr. 752, fol. 1r (E.T. De Wald, Vaticanus graecus 752. Illustrations in the Manuscripts of the Septuagint, 3. Psalms and Odes, pt. II, Princeton 1942, pl. 1); the birth of David in the Psalter of Dumbarton Oaks, Washington, D.C. DO. 3, fol. $5 \mathrm{r}$ (S. der Nersessian, Dumbarton Oaks Psalter and New Testament, DOP 19 (1965), 168, fig. 3) and the birth of Solomon in the Vat. gr. 333, fol. 51v (II Sam 12:24; Lassus, Livre des Rois, 75, fig. 93) belong to the same formula. For their discussion, see the author's Ph.D. dissertation (see n. *), 157-61.

${ }^{42}$ On the two women, see the depiction of Moses' birth (Ser., fol. 156r, Weitzmann and Bernabò, Octateuch, 144, fig. 596).

${ }^{43}$ Sor. Gyn. II.xix (Soranos, Gynaikia, vol. II, 15). The passage on What is the Care of the Woman after Labor does not appear in Temkin's version. 


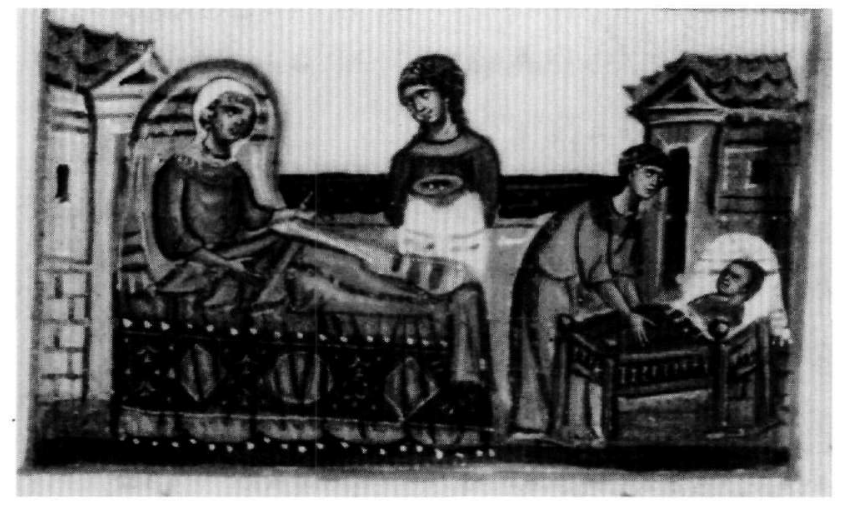

Fig. 5. Samson's birth, Rome, Lib. Apost. Vat., gr. 746, fol. 490r, c. 1150 (photo: Biblioteca Apostolica Vaticana).

infant was worth rearing and severed the umbilical cord ${ }^{44}$, the physician urged her to proceed without delay to bathe the newborn so as to remove the amniotic fluid from his body: "After having cleansed the body, one must bathe it with lukewarm water and wash away all the covering emulsion"45.

Ernst Kitzinger has argued that the Hellenistic motif of bathing the infant ${ }^{46}$ influenced illustrations in the early illuminated Bibles; these, in turn, were the source for the iconography of the New Testament, such as the Nativity ${ }^{47}$,

\footnotetext{
${ }^{44}$ Sor. Gyn. II.vi.10 (79)-vii.11 (80) (Temkin, Soranus' Gynecology, 7981).

45 "Taking fine and powdery salt, or natron or aphronitre, one must besprinkle the newborn..." (Sor. Gyn. II.viii (82) (Temkin, Soranus' Gynecology, 83).

${ }^{46}$ The Hellenistic Heritage in Byzantine Art, DOP 17 (1963), 100-105, n. 18-20, esp. 103, figs 6-7. See also A. Hermann, Das erste Bad des Heilands und des Helden in spätantiken Kunst und Legende, $J b A C h r 10$ (1967), 61-82.

${ }^{47}$ The most ancient Christian example of the bath appears in a mosaic in the Oratory of Pope John VII in the ancient church of St. Peter in Rome, dated to 705-708. There were possibly earlier examples, but not prior to the sixth century (P.J. Nordhagen, The Origin of the Washing of the Child in the Nativity Scene, Studies in Byzantine and Early Medieval Painting, ed. P. J. Nordhagen, London 1990, 326-31; S. Waetzold, Die Kopien des 17. Jahrhunderts nach Mosaiken und Wandmalerei in Rom, Munich 1964, nos 477-478).

${ }^{48}$ Kitzinger, Hellenistic Heritage, 100, 106, n. 131.

${ }^{49} \mathrm{~J}$. Lafontaine-Dosogne, Iconographie de l'enfance, vol. I, 104. Mentioned already in the Classical literature in connection with the birth of Dionysos (J. Harrison, Prolegomena to the Study of Greek Religion, New York 1955, 546-48; M.G. Parani, Reconstructing the Reality of Images. Byzantine Material Culture and Religious Iconography (11th-12th Centuries), Leiden and Boston 2003, 192-93, n. 188), the cradle appears in
}

and were then used to depict the biblical birth appearing in the Octateuchs ${ }^{48}$. Yet, our discussion suggests that the bath may have been introduced into the Octateuchs' imagery via the full-cycle illustrated in the Gynaikeia rather than along the arduous route suggested by Kitzinger. Two miniatures display a conflation of the pre- and post-partum stages.

A similar explanation can be suggested for the cradle appearing in several miniatures. Although it is stated that this element draws on the iconography of the birth of the Virgin from the twelfth century onward ${ }^{49}$, the cradle already appears in the eleventh century Vat. gr. 747 on fol. 26r, in which the baby Henoch lies on a large pillow, with his head raised high (Fig. 6). This depiction accords Soranus' instruction to put the swaddled newborn to bed ${ }^{50}$, “... for instance upon a pillow filled with flock, or otherwise, with soft hay; and the mattress should be hollowed out like a channel, so that the new born when put down should <not $>$ roll about. And the little head should be placed in a somewhat raised position..."51. Therefore, we cannot dismiss the possibility that the Byzantine artist replaced the various bed supports mentioned in Soranus' text with the cradle in order to incorporate an everyday item and thereby render a realistic atmosphere in the confinement room ${ }^{52}$. It seems, then, that both stages - the infant's bath and the swaddled baby placed on a bed support - were illustrated in the Gynaikeia and that the

biblical scenes already in the sixth century, as for example in the scene of Potiphar's wife in the Vienna Genesis (Gen. 39: 9-13; Vienna, Österreichische Nationalbibliothek, theol. gr. 31, fol. 16r (sixth century), H. Gerstinger, Die Wiener Genesis, Vienna: Filser, 1931, 156, pl. 31); or scenes of the Nativity from the seventh century on, as exemplified in the mosaic of the Oratory of Pope John VII in the ancient church of St. Peter in Rome (Nordhagen, Origin of the Washing, op.cit., 326).

${ }^{50}$ Sor. Gyn. II. ix.14 (83) (Temkin, Soranus' Gynecology, 84-85).

${ }^{51}$ Sor. Gyn. II.x.16 (85) (Temkin, Soranus' Gynecology, 87).

${ }^{52}$ A small couch for receiving the newborn baby, Alexios I Komnenos, probably designating a cradle, is mentioned in an unpublished sermon delivered by the cartophylax Samuel Mavropous on Lent 1180 (P. Magdalino, The Empire of Manuel I Komnenos, 1143-1180, Cambridge [U.K.] 1993, 243, n. 46). The insertion of realia into the biblical scenes of childbearing is not altogether surprising. Thus, for example, the presence of one or more young women bringing food or presents to the mother, drawing its iconography from Classical source, was convincingly anchored in the contemporary imperial custom of aristocratic women to pay homage to the empress after giving birth by bringing her presents (Constantin VII Porphyrogenetus, De cer. II, 21, Reiske, ed., Bonn, vol. I, 618). For the discussion of this element, see Lafontaine-Dosogne, Iconographie de l'enfance, vol. I, 97; S. Dufrenne, A propos de la naissance de David dans le Ms. 3 de Dumbarton Oaks, TM 8 (1981), 126; Der Nersessian, Dumbarton Oaks Psalter, op.cit. (n. 41), 168. 


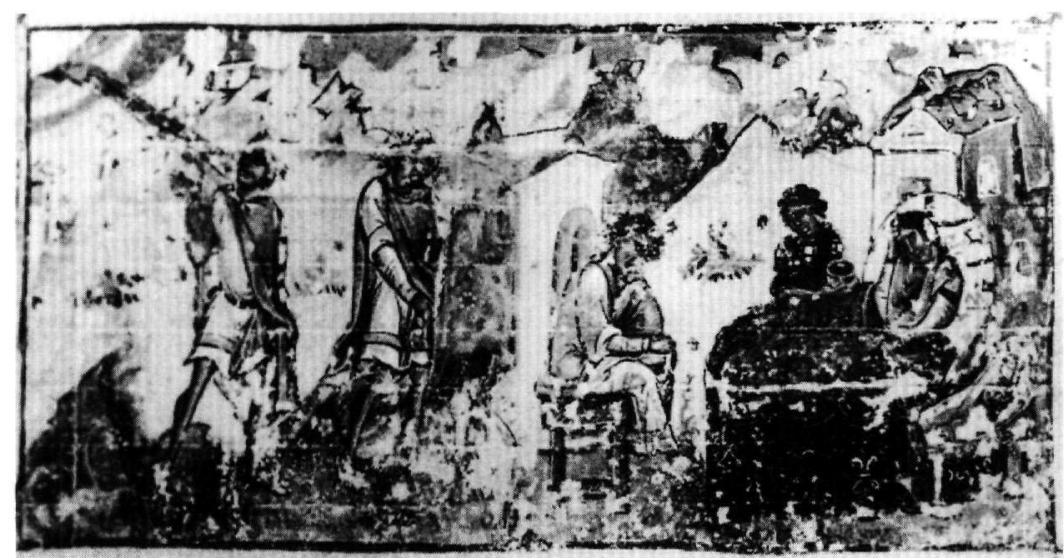

Fig. 6. The birth of Henoch, Rome, Lib. Apost. Vat., gr. 747, fol. 26r, c. 1070 (photo: Weitzmann and Bernabò, Octateuch, fig. 107). copyist of the Octateuch preferred to illustrate only one of them.

The discussion of the 'painless birth' schema shows clearly that it is portraying the post-partum stage described in Soranus' Book II and is harmoniously completing the pre-partum stage amply illustrated in Vat. gr. $747^{53}$, the closest manuscript to the Octateuch's archetype ${ }^{54}$. The birth of BenAmmi, conflating both schemas into one continuous unit, is a case in point. On the left side of the miniatures, Lot's daughter undergoes labor while seated on a bench, her left hand pressing down on her uterus - pre-partum elements; on the right side, Moab, the first-born, is lying in a cradle attended by the second daughter - a post-partum detail.

Our discussion of the hypothetical model of the iconography of childbearing in the Octateuchs suggests that the arche- type $^{55}$ drew specifically from a copiously illuminated manuscript of Book II of Soranus' Gynaikeia, reducing the entire iconographic formula to its most basic elements without diminishing from the scene's significance. This conclusion is corroborated by the extant Latin manuscripts illuminating the Cynaecia.

This supposition, on the one hand, challenges the widely accepted theory that the Octateuchs employ two independent iconographic formulas; on the other, it suggests a possible model for both 'realistic' and 'painless birth' iconography. If our hypothesis is sound, then one has to look for the origin of the biblical iconography of childbearing in the Soranian model, rather than in the New Testament iconography that, as modern scholarship maintains, was rerouted to the Octateuchs.

\footnotetext{
${ }^{53}$ Weitzmann and Bernabò, Octateuch, 81, fig. 283.

${ }^{54}$ Ibid., 9 .

${ }^{55}$ The ongoing debate on the formation and date of the Octateuch's archetype, whether in the sixth (K. Weitzmann, Illustrations in Roll and Codex. A Study of the Origins and Method of Text Illustration, Studies in Manuscript Illumination, 2 [Princeton, N.J., 1947; repr. 1970], esp. 13132, 190, 195, and 247; Weitzmann and Bernabò, Octateuch, 8, 299-311, 313-29) or eleventh century (J. Lowden, The Octateuchs: A Study in Byzantine Manuscript Illustration, University Park, Pa. 1992, 82-83, 102104, 121-23; id., The Beginning of Biblical Illustration, in Imaging the Early Medieval Bible (see n. 33), 9-59, esp. 55; id., The Transmission of 'Visual Knowledge' in Byzantium through Illuminated Manuscripts:
}

Approaches and Conjectures, in Literacy, Education and Manuscript Transmission in Byzantium and Beyond, eds. Catherine Holmes and $\mathbf{J u}-$ dith Waring, Leiden-Boston-Köln 2002, 59-80), should not interfere with our hypothesis, given the impact of the ambitious Macedonian imperial project of copying the Classical heritage (P. Lemerle, Premier humanisme byzantin. Notes et remarques sur enseignement et culture à Byzance des origines au Xe siècle, Paris 1971, esp. 177-204, 266-300; id., Le gouvernement des philosophes: notes et remarques sur l'enseignement, les écoles, la culture, Cinq études sur le XIe siècle byzantin, Paris 1977, 195-248; C. Mango, Byzantium and its Image. History and Culture of the Byzantine Empire and its Heritage, London 1984). 


\author{
Mati Meyer
}

\title{
ТО ЕІКОNОГРАФІКО ПРОТУПО TSN $\Sigma$ KHNQN $\Gamma E N N H \Sigma H \Sigma \Sigma T I \Sigma$ OKTATEYXOY $\Sigma$
}

$\Sigma$

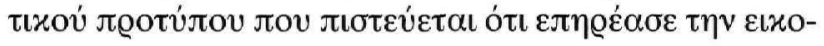

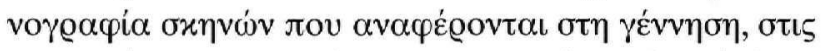

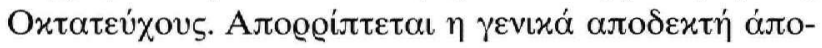

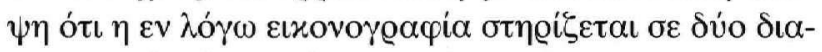

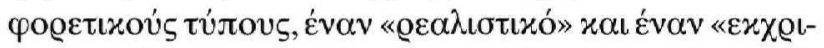

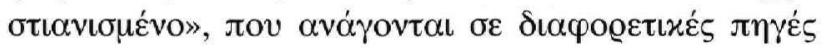

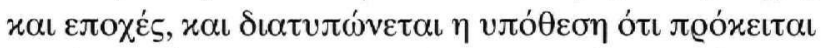

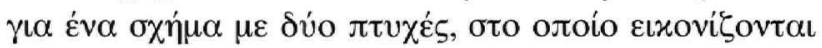

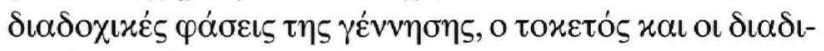

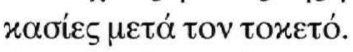

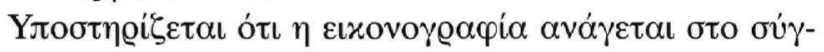

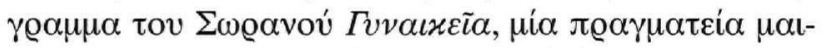

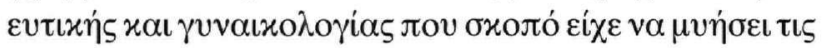

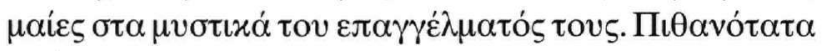

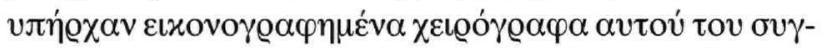

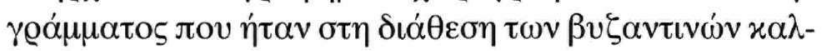

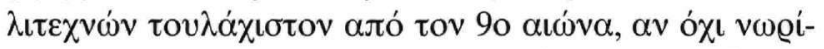

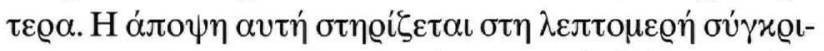

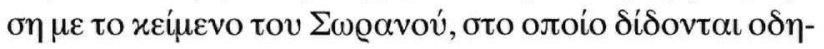

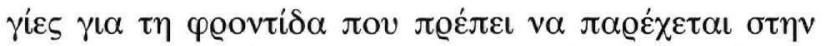

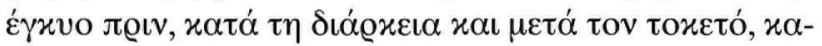

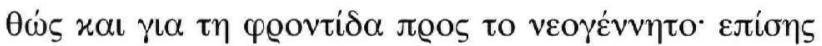

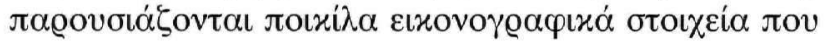

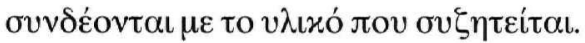

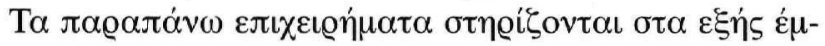

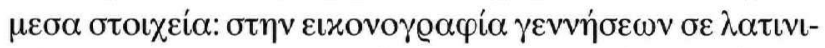

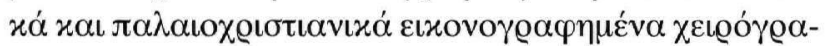

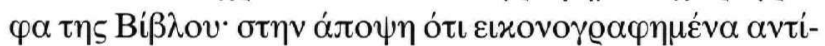

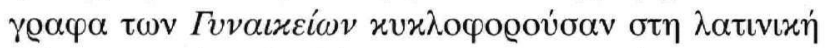

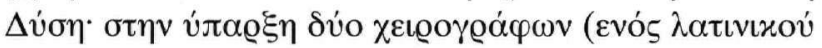

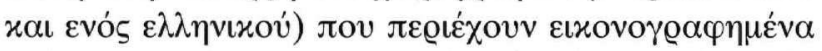

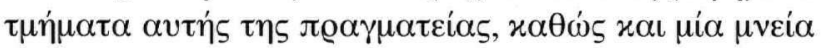

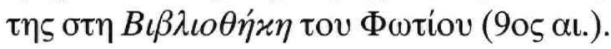

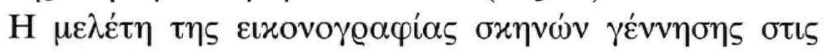

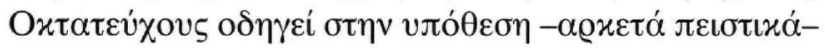

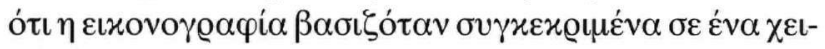

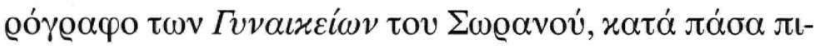

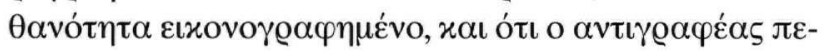

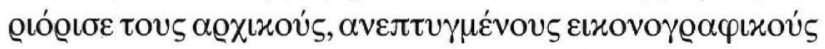

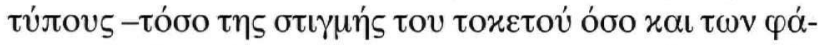

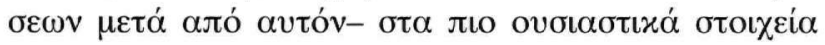

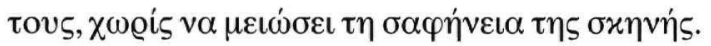

